\title{
THE ANALYSIS OF THE EFFECT OF THE ATM (AUTOMATED TELLER MACHINE) SERVICE DIMENSIONS ON CUSTOMERS SATISFACTION AT PT BANK PEMBANGUNAN DAERAH JAWA TENGAH BRANCH OFFICE OF KUDUS
}

\author{
Dhiah Fitriyani *) \\ Aris Sunindyo **) \\ Moh. Muslikh **) \\ *) dhiah.fitriyani12@gmail.com
}

\begin{abstract}
This research aims to identify factors - factors the quality of service that consists of tangible, reliability, responsiveness, assurance, empathy to customer satisfaction PT. Bank Pembangunan Daerah Jawa Tengah Branch Office of Kudus.

The population of this research is all of the customers at PT. Bank Pembangunan Daerah Jawa Tengah Branch Office of Kudus. The sampling technique uses the Accidental Sampling Method amounting to 100 customers. The data used in this research is the primary data obtained through the distribution of questionnaires. The data analysis model uses the Multiple Linear Regression Analysis Model. Meanwhile, data analysis techniques use the Statistical F Test, Coefficient of Determination (R2), and statistical $t$-Test.

The results of $t$ test are obtained the effect of variable responsiveness, assurance and empathy that significantly influence customer satisfaction of PT Bank Pembangunan Daerah Jawa Tengah Kudus Branch Office. Meanwhile reliability and tangible have no significant effect. In $F$ test, it is found that the dimension of ATM Service quality tangible, reliability, responsiveness, assurance, and empathy simultaneously have significant effect on the satisfaction of customers of the Central Java Regional Development Bank of the Branch Office Keywords: Customers Satisfaction, Dimensions of Service Quality, Tangibles, Reliability, Responsiveness, Assurance and Empathy.

*) Final Project Student of Banking and Finance Diploma Program, Accounting Department State Polytechnic of Semarang 2019.

**) Lecturer of Accounting Department, State Polytechnic of Semarang.
\end{abstract}

\section{INTRODUCTION}

\section{Background}

Banking as an institution that plays a role in financial transactions has used information technology which continues to develop. The community keeps the money in the bank, and the bank provides a stimulus in the form of remuneration to be given to the customers. These stimuli can be in the form of easy opening of a savings account, high interest, prizes/souvenirs, free transfer fees between accounts, ATM facilities, and security guarantees.

A large number of banks in Indonesia has resulted in a very tight level of banking competition. The increasing competition in the banking industry looks good in terms of the supply of products, services, and technological advancements which show more and more demands of the people that the banking world must be able to fulfill. To maintain the market, 
banks offer reliable products and services and almost all the features are no different. Therefore, for a bank to be different and win the competition, banks must have better service than others. This will determine which banking services to choose. The quality of service from good bank services is one of the most important factors for maintaining and attracting customers to keep choosing the company.

According to Parasuraman and Zeithaml (in Tjiptono, 2016:126) suggest that service quality is the level of excellence expected and control over the level of excellence to meet customer desires, in service quality there are several dimensions, namely tangible (physical evidence), reliability (reliability), responsive (assurance), assurance (assurance) and empathy (empathy). This is where banks provide automated services, namely through ATMs (Automatic Teller Machines). ATM facilities that are spread throughout Indonesia, which makes it easier for customers to take and deposit every day without being limited by space and time. The convenience provided through ATM services is the main attraction for customers. Service quality is reflected in consumer satisfaction to reuse Parasuraman et al (1993) services (in Hidayat, 2009). This makes ATMs important for bank especially BPD Jateng because of the efficiency of service and can reduce the work of employees and can reduce HR. The quality of ATM management is very dependent on the customer's assessment, so the company's orientation is not only emphasized on service quality but on the value and service expected by the customer so that it can have a positive influence on customer satisfaction. Improving the quality of ATM management services is intended to make customers feel happy after using an ATM. So that customers can use the ATM to the fullest.

Below is a table of rating for the Best 10 ATM BPD performance in Indonesia in 20172018 based on ratings obtained from Infobank Magazine. The best ATM performance results can be seen in the following table:

Table 1

Best Performance 10 ATM BPD in 2017-2018

\begin{tabular}{|c|c|c|c|}
\hline \multirow{2}{*}{ Rating } & \multirow{2}{*}{ Names of Banks } & \multicolumn{2}{|c|}{ Score $(\%)$} \\
\hline & & 2017 & 2018 \\
\hline 1 & Bank DKI & 100,00 & 100,00 \\
\hline 2 & Bank Jatim & 91,36 & 100,00 \\
\hline 3 & Bank Lampung & 93,64 & 99,43 \\
\hline 4 & Bank Sumsel Babel & 100,00 & 99,43 \\
\hline 5 & Bank Kalbar & 92,73 & 99,43 \\
\hline 6 & Bank Bengkulu & 99,15 & - \\
\hline 7 & Bank NTB & 99,77 & 98,58 \\
\hline 8 & Bank Riaukepri & 100,00 & 97,16 \\
\hline 9 & Bank Jateng & 100,00 & 97,16 \\
\hline 10 & Bank Kalsel & 99,77 & 96,18 \\
\hline
\end{tabular}

Sources: Infobank magazine (2018) 
Based on Table 1 Best Performance ATM results are obtained in 2018, it can be seen that PT Bank Pembangunan Daerah Jawa Tengah ranks 9th in the amount of 97.16\% in 2018 and has decreased by $2.84 \%$ from 2017 which is $100 \%$. This shows that ATM performance at PT Bank Jateng has decreased. And also supported by the news about customer complaints about the problem of ATM owned by PT. Bank Jateng. With this case, the customer feels that the ATM service owned by PT. Bank Jateng is less than satisfactory. This is a sign that PT Bank Pembangunan Daerah Jawa Tengah still has to conduct an evaluation and improve its performance. This improvement can be done by checking each ATM owned by PT Bank Jateng routinely, so that things like ATMs with errors can be handled properly and customers feel satisfied with the services provided by PT Bank Jateng.

\section{THEORITICAL FRAMEWORK}

Based on the results of previous research, it can be developed the framework that underlies this research. This research was conducted aimed to determine the effect of ATM service dimensions on customer satisfaction at PT Bank Pembangunan Daerah Jawa Tengah Branch Office of Kudus. The mindset can be seen as follows:

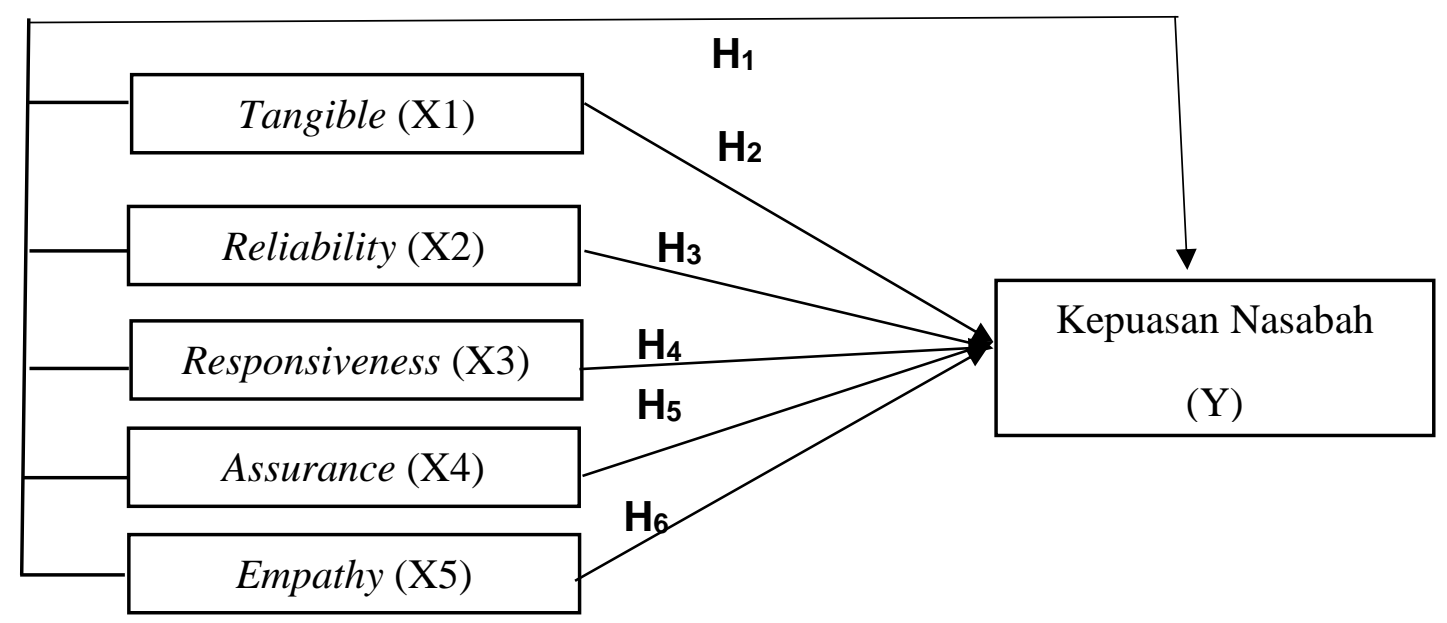

Source: Primary Data Processed (2019)

Figure 1 Theoretical Framework

\section{Relationship between Variables}

The following is an explanation of the relationship between the independent variable and the dependent variable.

1. Tangible with regard to the attractiveness of physical facilities, equipment, and materials used by the company, as well as the appearance of employees (Tjiptono 2016:137). The 
physical form, physical quality, and completeness of equipment can affect the level of customer satisfaction if it can provide comfort and security to its customers.

2. Reliability relating to the company's ability to provide accurate services from the first time without making any mistakes and delivering services in accordance with the agreed time (Tjiptono, 2016:137). Providing promising services quickly and accurately can affect the level of customer satisfaction. Customers will be more confident and satisfied if the bank provides good, fast, accurate, and promising services.

3. Responsiveness is the desire to help customers and provide services responsibly (Tjiptono, 2016:137). Customers have the desire and tend to demand that the company or the bank provide services that can fulfill its desires. If customers feel easier in making transactions, customers will feel satisfied.

4. Assurance guarantee that the behaviour of employees is able to foster customer confidence in the company and the company can create a sense of security for its customers (Tjiptono, 2016:137). Customers will feel satisfied and comfortable if the level of security and fluency in the transaction runs well and promises.

5. Empathy includes ease in relationships, good communication, personal attention, and understanding customer needs (Tjiptono, 2016:137). If the bank can help and solve problems faced by customers, the customer will feel satisfied).

\section{Hypothesis}

H1: It is assumed that the dimension of ATM service consisting of Tangible, Reliability, Responsiveness, Assurance, and Empathy simultaneously effects customers satisfaction at PT Bank Pembangunan Daerah Jawa Tengah Branch Office of Kudus.

$\mathrm{H} 2$ : It is assumed that the Tangible variable partially effects customers satisfaction at PT Bank Pembangunan Daerah Jawa Tengah Branch Office of Kudus.

H3: It is assumed that the Reliability variable partially effects customers satisfaction at PT Bank Pembangunan Daerah Jawa Tengah Branch Office of Kudus.

H4: It is assumed that the Responsiveness variable partially effects customers satisfaction at PT Bank Pembangunan Daerah Jawa Tengah Branch Office of Kudus.

H5: It is assumed that the Assurance variable partially effects customers satisfaction at PT Bank Pembangunan Daerah Jawa Tengah Branch Office of Kudus.

H6: It is assumed that the Empathy variable partially effects customers satisfaction at PT Bank Pembangunan Daerah Jawa Tengah Branch Office of Kudus. 


\section{METHODS}

\section{Data Types}

The research method is basically a scientific way to get data with specific purposes and uses (Sugiyono, 2015: 2). Based on this there are four key words that need to be considered, namely the scientific method, data, goals and uses. Whereas according to Narbuko (2008: 1) the research method comes from the word "Method" which means the right way to do something, and "Logos" which means science or knowledge. So the methodology means how to do something by using the mind carefully to achieve a goal.

\section{Populations and Samples}

The population is the whole object of the study either consisting of objects that are real, abstract, events or symptoms that are sources of data and have certain characteristics and the same (Sukandarrumidi 2006: 47). While Sugiyono (2015: 80) population is a generalization consisting of objects/subjects that have certain qualities and characteristics set by researchers to be studied and the conclusions drawn.

The sample is part of the number and characteristics possessed by the population (Sugiyono, 2015:118). If researchers conduct a study of a large population, while researchers want to examine the population and researchers have limited funds, energy and time, then researchers use sampling techniques, so that generalizations to the population studied. The meaning of the sample taken can represent or represent the population. According to Roscoe (1982: 253) in Sugiyono (2015: 91) explained that a decent sample size in the report was between 30 to 500 , therefore in this report the researchers distributed questionnaires totaling 100 questionnaires to 100 respondents in accordance with the requirements or criteria which has been specified.

\section{Data Analysis Method}

The test that did by author to analyse the data are descriptive statistical test, classic assumption test, multiple regression analysis test, $\mathrm{F}$ test, $\mathrm{t}$ test, Koefisian determination test using SPSS 25.

\section{RESULT AND DISCUSSION \\ Analysis of Multiple Linear Regression}

In the analysis of multiple linear regression, in addition to seeing how the conditions or changes in the dependent variable when there is a change in the independent variable, it also shows the direction of the relationship between the dependent variable (satisfaction) with the independent variable (Tangible, Reliability, Responsiveness, Assurance and Empathy). 
Table 2 Multiple Linear Analysis Test Results

ANOVAa

\begin{tabular}{|r|l|r|r|r|r|c|}
\hline \multicolumn{2}{|l|}{ Model } & \multicolumn{1}{c|}{$\begin{array}{c}\text { Sum of } \\
\text { Squares }\end{array}$} & \multicolumn{1}{c|}{ df } & $\begin{array}{c}\text { Mean } \\
\text { Square }\end{array}$ & F & Sig. \\
\hline \multirow{3}{*}{1} & Regression & 110.850 & 5 & 22.170 & 15.545 & $.000^{\mathrm{b}}$ \\
\cline { 2 - 7 } & Residual & 134.060 & 94 & 1.426 & & \\
\cline { 2 - 7 } & Total & 244.910 & 99 & & & \\
\hline
\end{tabular}

a. Dependent Variable: Kepuasan

b. Predictors: (Constant), Empathy, Responsiveness, Reliability, Tangible,

Assurance

\section{Coefficients ${ }^{\mathbf{a}}$}

\begin{tabular}{|c|c|c|c|c|c|c|c|c|}
\hline \multirow{2}{*}{\multicolumn{2}{|c|}{ Model }} & \multicolumn{2}{|c|}{$\begin{array}{l}\text { Unstandardize } \\
\text { d Coefficients }\end{array}$} & \multirow{2}{*}{$\begin{array}{c}\text { Standardized } \\
\text { Coefficients } \\
\text { Beta } \\
\end{array}$} & \multirow[b]{2}{*}{$\mathrm{t}$} & \multirow[b]{2}{*}{ Sig. } & \multicolumn{2}{|c|}{$\begin{array}{c}\text { Collinearity } \\
\text { Statistics }\end{array}$} \\
\hline & & B & $\begin{array}{l}\text { Std. } \\
\text { Error }\end{array}$ & & & & $\begin{array}{c}\text { Toleranc } \\
\mathrm{e}\end{array}$ & VIF \\
\hline \multirow[t]{6}{*}{1} & (Constant) & -.124 & 1.785 & & -.069 & .945 & & \\
\hline & Tangible & -.154 & .082 & -.161 & -1.876 & .064 & .793 & 1.262 \\
\hline & Reliability & .049 & .091 & .043 & .544 & .588 & .951 & 1.052 \\
\hline & Responsiveness & .181 & .089 & .166 & 2.041 & .044 & .884 & 1.132 \\
\hline & Assurance & .711 & .087 & .722 & 8.212 & .000 & .753 & 1.328 \\
\hline & Empathy & .170 & .081 & .169 & 2.109 & .038 & .903 & 1.107 \\
\hline
\end{tabular}

a. Dependent Variable: Kepuasan

Source: Primary Data Processed (2019)

Based on Table 2 above, we get the following linear regression equation:

\section{Customer Satisfaction $=-0,124-0,154$ Tangible + 0,049 Reliability + 0,181} Responsiveness + 0,711 Assurance + 0,170 Empathy + e.

In the multiple linear regression model above can be described as follows:

1. A constant of -124 states that if the independent variable is considered constant, then the average for customer satisfaction PT. Bank Pembangunan Daerah Jawa Tengah Branch Office of Kudus has a value of -124 .

2. Each contribution given by the tangible variable (X1) has a regression coefficient with a positive sign $(+)$ of 0.154 . This illustrates that an increase in the value of tangible variables by 1 (one) unit will result in a decrease in customer satisfaction PT Bank Pembangunan Daerah Jawa Tengah Branch Office of Kudus of 0.154 assuming the other variables are fixed.

3. Each contribution given by the reliability variable $(\mathrm{X} 2)$ has a positive $(+)$ regression coefficient of 0.049 . This illustrates that an increase in the value of the reliability variable by 1 (one) unit will result in an increase in customer satisfaction PT Bank Pembangunan Daerah Jawa Tengah Branch Office of Kudus of 0.049 with the assumption that other variables are fixed. 
4. Each contribution made by the responsiveness variable (X3) has a positive $(+)$ regression coefficient of 0.181 . This illustrates that an increase in the value of responsiveness by 1 (one) unit will result in an increase in customer satisfaction PT Bank Pembangunan Daerah Jawa Tengah Branch Office of Kudus of 0.181 with the assumption that other variables are fixed.

5. Each contribution made by the assurance variable (X4) has a positive (+) regression coefficient of 0.711 . This illustrates that an increase in the value of the assurance variable by 1 (one) unit will result in increased customer satisfaction PT Bank Pembangunan Daerah Jawa Tengah Branch Office of Kudus of 0.711 assuming other variables are fixed.

6. Each contribution given by empathy variable (X5) has a positive (+) marked regression coefficient of 0.170 . This illustrates that an increase in empathy variable value of 1 (one) unit will result in an increase in customer satisfaction PT Bank Pembangunan Daerah Jawa Tengah Branch Office of Kudus of 0.170 with the assumption that other variables are fixed.

\section{F Test (Simultaneous Test)}

The F statistical test basically shows whether all independent variables entered in the model have a joint influence on the dependent variable (Ghozali, 2013: 98).

1. If $\mathrm{F}$ count is greater than Ftable, then Ho is rejected and accepts Ha.

2. If the significance value is smaller than $\alpha=5 \%$, then Ho is rejected or accepts Ha.

The results of simultaneous significance test calculations can be seen in Table 3 .

\section{Table 3 F Test Results}

ANOVA ${ }^{\mathrm{a}}$

\begin{tabular}{|c|c|c|c|c|c|c|}
\hline \multicolumn{2}{|c|}{ Model } & $\begin{array}{c}\text { Sum of } \\
\text { Squares }\end{array}$ & df & $\begin{array}{c}\text { Mean } \\
\text { Square }\end{array}$ & F & Sig. \\
\hline \multirow{3}{*}{1} & Regression & 110.850 & 5 & 22.170 & 15.545 & $.000^{\mathrm{b}}$ \\
\cline { 2 - 7 } & Residual & 134.060 & 94 & 1.426 & & \\
\cline { 2 - 7 } & Total & 244.910 & 99 & & & \\
\hline
\end{tabular}

a. Dependent Variable: Kepuasan

b. Predictors: (Constant), Empathy, Responsiveness, Reliability, Tangible, Assurance

Source: Primary Data Processed (2019)

Based on the results of the F statistical test in Table 4.3 the value of Fcount is 15.545 and the significance is 0.000 which when compared to Ftable (significance level of $5 \%$, the amount of data 100 , and the number of independent variables 5) is 2.31 , then the value of Fcount is 
greater than Ftable thus also with a probability of error of 0,000 which is below 0.05 or $5 \%$, so $\mathrm{Ho}$ is rejected and $\mathrm{Ha}$ is accepted. This shows that tangible variables, reliability, responsiveness, assurance, and empathy simultaneously have a significant effect on customer satisfaction. Hypothesis 1 which states "It is assumed that the dimension of ATM service consisting of Tangible, Reliability, Responsiveness, Assurance, and Empathy simultaneously effects customer satisfaction at PT. Bank Pembangunan Daerah Jawa Tengah Branch Office of Kudus" is accepted.

\section{t Test (Partial Test)}

The statistical test $\mathrm{t}$ basically shows how far the influence of one independent variable individually in explaining the dependent variable (Ghozali, 2013: 98). Tests carried out using a significant level of $0.05(\alpha=5 \%)$. Acceptance or rejection of the hypothesis is done by the criteria: 1. If the value is significant $>0.05$ then the hypothesis is rejected (regression coefficient is not significant). This means that partially independent variables do not have a significant effect on the dependent variable.

The results of the t test calculations can be seen in the table below:

Table $4 \mathrm{t}$ Test Result

Coefficients $^{\mathbf{a}}$

\begin{tabular}{|c|c|c|c|c|c|c|c|c|}
\hline & & \multicolumn{2}{|c|}{$\begin{array}{l}\text { Unstandardized } \\
\text { Coefficients }\end{array}$} & \multirow{2}{*}{$\begin{array}{c}\begin{array}{c}\text { Standardized } \\
\text { Coefficients }\end{array} \\
\text { Beta }\end{array}$} & \multirow[b]{2}{*}{$\mathrm{t}$} & \multirow[b]{2}{*}{ Sig. } & \multicolumn{2}{|c|}{$\begin{array}{c}\text { Collinearity } \\
\text { Statistics }\end{array}$} \\
\hline \multicolumn{2}{|c|}{ Model } & $\mathrm{B}$ & Std. Error & & & & Tolerance & VIF \\
\hline \multirow[t]{6}{*}{1} & (Constant) & -.124 & 1.785 & & -.069 & .945 & & \\
\hline & Tangible & -.154 & .082 & -.161 & -1.876 & .064 & .793 & 1.262 \\
\hline & Reliability & .049 & .091 & .043 & .544 & .588 & .951 & 1.052 \\
\hline & Responsiveness & .181 & .089 & .166 & 2.041 & .044 & .884 & 1.132 \\
\hline & Assurance & .711 & .087 & .722 & 8.212 & .000 & .753 & 1.328 \\
\hline & Empathy & .170 & .081 & .169 & 2.109 & .038 & .903 & 1.107 \\
\hline
\end{tabular}

a. Dependent Variable: Kepuasan

Source: Primary Data Processed (2019)

Based on the $t$ test the results can be seen in Table 4.13 and will be explained as follows:

1. Hypothesis testing 2 (Tangible) the results of data processing above indicate that the value of tcount $<$ ttable $(-1,876<1,986)$ with a significant level of 0.064 (more than 0.05). This shows that the tangible influence on customer satisfaction PT Bank Pembangunan Daerah Jawa Tengah Branch Office of Kudus is a negative and not significant effect. Thus hypothesis 2 (two) which states" It is assumed that the Tangible variable partially effects customer satisfaction at PT. Bank Pembangunan Daerah Jawa Tengah Branch Office of Kudus" is rejected. 
2. Hypothesis testing 3 (Reliability) the results of data processing above shows that the value of tcount $<$ ttable $(0.544<1.986)$ with a significant level of 0.588 (more than 0.05 ). This shows that the reliability of customer satisfaction PT Bank Pembangunan Daerah Jawa Tengah Branch Office of Kudus is a positive and not significant effect. Thus, hypothesis 3 (three) which states "It is assumed that the Reliability variable partially effects customer satisfaction at PT Bank Pembangunan Daerah Jawa Tengah Branch Office of Kudus" is rejected.

3. Hypothesis testing 4 (Responsivness) the data processing results above show that the value of tcount $>$ ttable $(2,041>1,986)$ with a significant level of 0.044 (less than 0.05). This shows that the effect of responsiveness on customer satisfaction of PT Bank Pembangunan Daerah Jawa Tengah Branch Office of Kudus is a positive and significant effect. Thus, hypothesis 4 (four) which states " It is assumed that the Responsiveness variable partially effects customer satisfaction at PT Bank Pembangunan Daerah Jawa Tengah Branch Office of Kudus " is accepted.

4. Hypothesis testing 5 (Assurance) the results of data processing above indicate that the value of tcount $>$ ttable $(8.212>1.986)$ with a significant level of 0.000 (less than 0.05$)$. This shows that the effect of assurance on customer satisfaction PT Bank Pembangunan Daerah Jawa Tengah Branch Office of Kudus is a positive and significant effect. Thus, hypothesis 5 (five) which states that "It is assumed that the Assurance variable partially effects customer satisfaction at PT Bank Pembangunan Daerah Jawa Tengah Branch Office of Kudus " is accepted.

5. Hypothesis testing 6 (Empathy) the results of data processing above indicate that the value of tcount > ttable $(2.109>1.986)$ with a significant level of 0.038 (less than 0.05$)$. This shows that the influence of empathy on customer satisfaction PT Bank Pembangunan Daerah Jawa Tengah Branch Office of Kudus is a positive and significant effect. Thus, hypothesis 6 (six) which states " It is assumed that the Empathy variable partially effects customer satisfaction at PT Bank Pembangunan Daerah Jawa Tengah Branch Office of Kudus " is accepted.

\section{Coefficient of Determination Test (R2)}

The coefficient of determination (R2) essentially measures how far the model's ability to explain variations in the dependent variable. The coefficient of determination is between zero and one. A small R2 value means that the ability of the independent variables to explain the variation of the dependent variable is very limited. A value close to one means that the 
independent variables provide almost all the information needed to predict variations in the dependent variable (Imam Ghozali, 2018: 98).

Table 5 Determination of Coefficient (R2) Test Results

Model Summaryb

\begin{tabular}{|r|r|r|r|}
\hline Model & \multicolumn{1}{|c|}{$\mathrm{R}$} & \multicolumn{1}{c|}{ R Square } & \multicolumn{2}{c|}{$\begin{array}{c}\text { Adjusted R } \\
\text { Square }\end{array}$} \\
\hline 1 & $.673^{\mathrm{a}}$ & .453 & .423 \\
\hline
\end{tabular}

a. Predictors: (Constant), Empathy, Responsiveness, Reliability, Tangible,

Assurance

b. Dependent Variable: Kepuasan

Source: Primary Data Processed (2019)

Based on Table 5 above, it can be seen that the coefficient of determination (Adjusted $\mathrm{R}$ Square) of 0.423 . This shows that $42 \%$ of PT Bank Pembangunan Daerah Jawa Tengah Branch Office of Kudus is influenced by tangible, reliability, responsiveness, assurance, and empathy variables. While the rest $(100 \%-42 \%=58 \%)$ is explained by other causes not determined in this research.

\section{RESULT AND DISCUSSION}

\section{Tangible Effect on Customer Satisfaction}

The results of the multiple linear regression test showed that Tangible had no effect on customer satisfaction of PT Bank Pembangunan Daerah Jawa Tengah Branch Office of Kudus and has a negative direction. This means that hypothesis 2 which reads "Tangible partially has a significant effect on customer satisfaction at PT Bank Pembangunan Daerah Jawa Tengah Branch Office of Kudus " is rejected. Tangible effect on customer satisfaction BPD Jateng that is not significant, meaning that the effect is meaningless. Based on observations made during the study, tangible that occurred at BPD Jateng Kudus there are several obstacles such as ATM buildings that are less extensive, less clean ATM rooms and ATM rooms that are less cold due to problems with the AC (Putri Andriani, 2013).

\section{Reliability Effect on Customer Satisfaction}

The results of the multiple linear regression test showed that Reliability had no effect on customer satisfaction of PT Bank Pembangunan Daerah Jawa Tengah Branch Office of Kudus and has a positive direction. This means that hypothesis 3 which reads "Reliability partially has a significant effect on customer satisfaction at PT Bank Pembangunan Daerah Jawa Tengah Branch Office of Kudus " is rejected. Reliability effect on customer satisfaction BPD Jateng Kudus that is not significant, meaning that the effect is meaningless. Based on observations 
made during the study, the reliability that occurs at BPD Jateng Kudus there are several obstacles such as not always 24-hour online because there is a disruption in the ATM network, then it is difficult to find an ATM BPD Central Java that provides cash deposit facilities (Putri Andriani, 2013).

\section{Responsiveness Effect on Customer Satisfaction}

The results of the multiple linear regression test show that the responsiveness influences the customer satisfaction of PT Bank Pembangunan Daerah Jawa Tengah Branch Office of Kudus and has a positive direction. This means that hypothesis 4 which reads "Responsiveness has a significant effect on customer satisfaction of PT Bank Pembangunan Daerah Jawa Tengah Branch Office of Kudus "accepted and has a positive direction. Responsiveness effect on customer satisfaction BPD Jateng Kudus has a high level of significance, this is seen from the $\mathrm{t}$ test where tcount $>$ ttable. Thus, the higher the level of trust, the higher customer satisfaction with PT. BPD Jateng Kudus (Dirwan and Ayu Pertiwi, 2017).

\section{Assurance Effect on Customer Satisfaction}

The results of the multiple linear regression test showed that assurance affects the customer satisfaction of PT Bank Pembangunan Daerah Jawa Tengah Branch Office of Kudus and has a positive direction. This means that hypothesis 5 which reads "Assurance has a significant effect on customer satisfaction of PT Bank Pembangunan Daerah Jawa Tengah Branch Office of Kudus "is accepted and has a positive direction.

Assurance effect on customer satisfaction BPD Jateng Kudus has a high level of significance, this is seen from the $t$ test where tcount $>$ ttable. Thus, the higher the level of trust, service quality, and employee knowledge, the higher customer satisfaction with PT. BPD Jateng Kudus (Rahmi Rosita, 2015).

\section{Empathy Effect on Customer Satisfaction}

The results of the multiple linear regression test show that empathy affects the customers satisfaction of PT Bank Pembangunan Daerah Jawa Tengah Branch Office of Kudus and has a positive direction. This means that hypothesis 6 which reads "Empathy has a significant effect on customer satisfaction of PT Bank Pembangunan Daerah Jawa Tengah Branch Office of Kudus "accepted and has a positive direction.

The empathy effect on customer satisfaction of BPD Jateng Kudus has a high level of significance, this is seen from the $t$ test where tcount $>$ ttable. This happens because BPD Jateng Kudus employees at pay attention to all customers complaints and are willing to help customers and answer visitors' questions kindly. Thus, the higher the level of service quality, and 
employee attitudes in handling customer complaints properly, the higher customer satisfaction with BPD Jateng Kudus (Ayu et.al., 2018).

The 5 (five) hypotheses developed form the basis of development in this study. F test results indicate that the results of this study are decent or have good goodness of fit. This means that tangible, reliability, responsiveness, assurance, and empathy variables simultaneously influence customers satisfaction of BPD Jateng Kudus (Rahmi Rosita, 2015) and (Putri Andriani, 2015). Then, the results of the $\mathrm{F}$ test were strengthened by the results of the Determination Coefficient (R2) test and showed a coefficient of determination (Adjusted R Square) of $42 \%$ and the remaining $58 \%$ was influenced by other variables not examined in this study due to other factors.

\section{CONCLUSIONS AND SUGGESTIONS}

\section{Conclusion}

The conclusions of this research as follows:

Based on this study with the title analysis of the influence of ATM services on customer satisfaction at PT Bank Pembangunan Daerah Jawa Tengah Branch Office of Kudus which has a Customer Satisfaction regression model $=-0,124-0,154$ Tangible +0.049 Reliability + 0,181 Responsiveness + 0,711 Assurance + 0,170 Empathy + e can be concluded as follows:

1. Tangible, Reliability, Responsiveness, Assurance, Empathy Simultaneously have a significant effect on customer satisfaction at PT Bank Pembangunan Daerah Jawa Tengah Kudus Branch Office because the value can be seen that the results of the Fcount $>$ Ftable $(15,545>2.31)$ with a significant level of 0,000 (less than 0.05$)$.

2. Tangible partially negative and insignificant effect on customer satisfaction at PT Bank Pembangunan Daerah Jawa Tengah Branch Office of Kudus because the tcount $<$ ttable $(-1,876<1,986)$ with a significant level of 0.064 (more than 0.05$)$ so that Ho is accepted and Ha rejected.

3. Reliability is partially positive and not significant effect on customer satisfaction at PT Bank Pembangunan Daerah Jawa Tengah Branch Office of Kudus because the value of tcount tcount $<$ ttable $(0.544<1.986)$ with a significant level of 0.588 (more than 0.05 ), so Ho is accepted and Ha rejected.

4. Responsiveness partially has a positive and significant effect on customer satisfaction at PT Bank Pembangunan Daerah Jawa Tengah Branch Office of Kudus because the value 
of tcount $>$ ttable $(2.041>1.986)$ with a significant level of 0.044 (less than 0.05$)$, so that Ho is rejected and Ha accepted.

5. Assurance partially positive and significant effect on customer satisfaction at PT Bank Pembangunan Daerah Jawa Tengah Branch Office of Kudus because the value of tcount $>$ ttable $(8.212>1.986)$ with a significant level of 0.000 (less than 0.05$)$, so that Ho is rejected and Ha is accepted.

6. Empathy partially has a positive and significant effect on customer satisfaction at PT Bank Pembangunan Daerah Jawa Tengah Branch Office of Kudus because tcount $>$ ttable $(2.109>1.986)$ with a significant level of 0.038 (less than 0.05$)$, so that Ho is rejected and $\mathrm{Ha}$ be accepted.

\section{Limitations of Research}

Some limitations of the research that can be drawn from this study as follows:

1. The results of the t test indicate that there are two insignificant variables, each of which is reliability which obtained a sig value of 0.588 and tangible which obtained a sig value of $0.064>0.05$ (greater than 0.05 )

2. The results of the coefficient of determination (Adjusted R Square) are only $42 \%$. This shows that the customer satisfaction of BPD Jateng Kudus is less able to be explained by tangible, reliability, responsiveness, assurance, empathy variables. The remaining $58 \%$ have other influences not examined in this study.

\section{Upcoming Research Agenda}

The next research related to this result, writer might consider to the following suggestions for better and more accurate research results:

1. In connection with reliability and tangible variables that show less supportive results, it is expected that future research can add other variables such as performance, features, conformance to specifications, durability, and aesthetics with references from the Prawitasari journal (2016) that are expected to increase customers satisfaction at PT Bank Pembangunan Daerah Jawa Tengah Branch Office of Kudus. So that the results of future research are expected to be better and able to improve the shortcomings or limitations in this research.

2. The scope of the research object is still limited, therefore it is suggested that further research expand the scope of the research object. 


\section{BIBLOGRAPHY}

Ambarwati, Yulian Belinda. 2014. Pengaruh Kualitas Pelayanan terhadap Kepuasan Nasabah di PT. Bank Central Asia (BCA) Tbk Cabang Undaan Surabaya. Jurnal Akuntansi ISSN: 2502-6380.

Andriani, Putri. 2015. Faktor-Faktor yang Mempengaruhi Kepuasan Nasabah Pengguna ATM (Studi pada Bank BNI Syariah Cabang Yogyakarta). Yogyakarta. UIN Sunan Kalijaga.

Bank Indonesia. Undang-Undang Republik Indonesia Nomor 10 Tahun 1998 Tentang Perbankan

Dirwan dan Pertiwi. 2017. Pengaruh Kenyamanan dan Kemudahan Penggunaan ATM BNI Taplus Terhadap Kepuasan Nasabah pada Bank Negara Indonesia Kantor Cabang Utama Makasar. Sekolah Tinggi Ilmu Ekonomi Nobel Indonesia Makasar.

Ghozali, Imam. 2018. Aplikasi Analisis Multivariate Dengan Program IBM SPSS 25. Semarang: Badan Penerbit Universitas Diponegoro.

Grace, Diana. 2017. Analisis Pengaruh Automatic Teller Machine dan Short Message Service Bannking terhadap Kepuasan Nasabah. Jurnal Elekronik Sistem Informasi dan Komputer Volume 3 No. 1. Palu. Sekolah Tinggi Manajemen Informatika dan Komputer (STMIK) Bina Mulia.

Hasan, Iqbal. 2010. Analisis Data Penelitian dengan Statistik. Jakarta: Bumi Aksara.

Kasmir, 2014. Dasar-Dasar Perbankan. Jakarta: PT. Rajagrafindo Persada.

Narbuko, Cholid dkk. 2008. Metodologi Penelitan. Jakarta: Bumi Aksara.

Nurmalasari, Eva. Wahyu Widodo dan Regina Jokom. 2016. Pengaruh Dimensi Kualitas Layanan Terhadap Kepuasan Konsumen di Hotel Zoom Surabaya. Surabaya. Universitas Kristen Petra Surabaya.

Pawestriningtyas, Nining Catur. Suharyono dan Imam Suyadi. 2016. Pengaruh Kualitas Pelayanan Jasa Terhadap Kepuasan Nasabah (Survei Pada Nasabah Perum Pegadaian Kantor Cabang Syariah Tlogomas Malang). Jurnal Administrasi Bisnis (JAB) Vol. 32 No. 2. Malang. Universitas Brawijaya Malang.

Prawitasari, Nita Dwi. 2016. Pengaruh Produk ATM Suka-Suka Terhadap Kepuasan Nasabah Bank Tabungan Negara (BTN) Cabang Madiun. The $7^{\text {th }}$ FIPA (Forum Ilmiah Pendidikan Akuntansi. Madiun. IKIP PGRI Madiun.

Qurniawati, Retno Budi Lestari dan Megawati. 2018. Analisis Pengaruh Tangible, Reliability,

Responsiviness, Assurance dan Empathy terhadap Kepuasan Pelanggan pada Wisata Air Amanzi Waterpark Palembang. E-Jurnal Manajemen STIE MDP. 
Ratnasari, Ririn Tri. 2011. Teori dan Kasus Manajemen Pemasaran Jasa. Bogor: Ghalia Indonesia.

Rizqy, Mukeri Warso dan Aziz Fathoni. 2016. Pengaruh Kualitas Pelayanan terhadap Kepuasan konsumen (Studi Kasus pada PT. Graha Service Indonesia Cabang Semarang. Jurnal Manajemen Vol. 2 No. 2. Universitas Pandanaran Semarang.

Rosita, Rahmi. 2015. Pengaruh Kualitas Pelayanan terhadap Kepuasan Nasabah BNI, BRI, Bank Mandiri dan BCA di Bekasi. E-Journal WIDYA Ekonomika Vol. 1.

Sarjono dan Julianita. 2011. SPSS vs LISREL: Sebuah Pengantar, Aplikasi untuk Riset. Jakarta: Salemba Empat.

Sembiring dan Wardhana. 2015. Pengaruh Kualitas Pelayanan Teller Terhadap Kepuasan Nasabah pada PT. Bank Rakyat Indonesia (Persero) Tbk., Kantor Unit Kemang Cabang Bogor. E-Jurnal Manajemen Vol. 2, No. 1. Universitas Telkom.

Sugiyono. 2015. Metode Penelitian Kuantitatif, Kualitatif, dan R\&D. Bandung: Alfabeta.

Syilvani, Muntiyas. 2016. Pengaruh Kualitas Pelayanan terhadap Kepuasan Nasabah Bank BNI Syariah Cabang Kusumanegara Yogyakarta. UIN Sunan Kalijaga.

Tjiptono, Fandy. 2016. Service, Quality dan Satisfaction. Yogyakarta: Andi Offset.

Wiyanto. 2016. Analisis Pengaruh Kualitas Pelayanan terhadap Kepuasan Tinggi dan Rendah Nasabah di Bank Syari'ah Mandiri Cabang Salatiga. Salatiga. Institut Agama Islam Negeri Salatiga.

Yulianti, Fadma. 2013. Pengaruh Kualitas Pelayanan terhadap Kepuasan Nasabah Tabungan pada Bank Panin Tbk KCP A. Yani Banjarmasin. Jurnal SPREAD Vol. 3 No. 3. STIE Indonesia Banjarmasin.

Zainurossalamia, Saida. 2014. Analisis Pelayanan Terhadap Kepuasan dan Loyalitas Nasabah Bank Kaltim Cabang Pembantu Kota Bangun. Jurnal Eksekutif Volume 11 No. 2. Samarinda. Universitas Mulawarman Samarinda

www.bankjateng.co.id http://sigitbayoenugroho.blogspot.com/2011/03/pengertian-atm.html http://spicytwentyone.blogspot.com/2017/05/uji-asumsi-klasik.html http://adeletorn.blogspot.com/2018/04/pengertian-populasi-dan-sampel-menurut.html 